\title{
Tarnished Plant Bug, Lygus lineolaris (Palisot de Beauvois) (Insecta: Heteroptera: Miridae) ${ }^{1}$
}

Wayne N. Dixon and T. R. Fasulo

\section{Introduction}

Lygus lineolaris (Palisot de Beauvois), the tarnished plant bug, attacks a wide variety of economically important herbaceous plants, vegetable crops, commercial flower plants, fruit trees, and nursery stock (Kelton 1975). In fact, over half of the cultivated plant species grown in the United States are listed as host plants for tarnished plant bugs (Capinera 2001).

Less well known, but of increasing importance, is that L. lineolaris feeds on conifer seedlings. Coniferous nursery stock in British Columbia, Oregon, Florida, Mississippi, Arkansas, and Oklahoma has been damaged by L. lineolaris (Schowalter et al. 1986, Shrimpton 1985, South 1986). Approximately $50 \%$ of the loblolly pine seedlings in one southern forest nursery was damaged by L. lineolaris (South 1986). In early 1989, the risk of feeding damage by L. lineolaris prompted several Florida forest nurseries to initiate preventive insecticide applications. In one nursery, by late May 1989 , non-treated plots of bare-root pine averaged 18.5 live pine seedlings/square foot, of which $24 \%$ exhibited feeding damage by L. lineolaris, while in insecticide-treated plots a density of 24 live pine seedlings/square foot and $2 \%$ damage was observed. Pine seedlings in a nursery severely damaged by $L$. lineolaris usually do not survive the growing season.

\section{Distribution}

L. lineolaris occurs in all Canadian provinces, the continental United States (excluding Hawaii), and most of the states of Mexico (Kelton 1975, Young 1986).

\section{Description}

\section{Adult}

Male: length 4.90-5.95 mm, width 2.38-3.01 $\mathrm{mm}$; female: length 5.25-5.95 mm, width 2.52-3.01 $\mathrm{mm}$. The head is yellowish-brown, frons smooth with black submedian lines. Rostrum 2.17-2.52 mm long. Pronotum yellowish to reddish brown, anterior angles rounded. Mesoscutum black, lateral areas pale or reddish. Hemelytra (anterior wings) reddish brown, pubescence moderately long and dense, yellowish.

1. This document is EENY-245 (originally published as DPI Entomology Circular 320), one of a series of Featured Creatures from the Entomology and Nematology Department, Florida Cooperative Extension Service, Institute of Food and Agricultural Sciences, University of Florida. Published: November 2001. This document is also available on Featured Creatures Website at http://creatures.ifas.ufl.edu. Please visit the EDIS Website at http://edis.ifas.ufl.edu and the Entomology and Nematology Department website at http://entnemdept.ifas.ufl.edu/.

2. Wayne N. Dixon, Florida Department of Agriculture and Consumer Services, Division of Plant Industry, and T.R. Fasulo, Department of Entomology and Nematology, Institute of Food and Agricultural Sciences, University of Florida, Gainesville.

The Institute of Food and Agricultural Sciences (IFAS) is an Equal Employment Opportunity - Affirmative Action Employer authorized to provide research, educational information and other services only to individuals and institutions that function without regard to race, creed, color, religion, age, disability, sex, sexual orientation, marital status, national origin, political opinions or affiliations. For information on obtaining other extension publications, contact your county Cooperative Extension Service office. Florida Cooperative Extension Service / Institute of Food and Agricultural Sciences / University of Florida / Larry R. Arrington, Interim Dean 
Summer adult color varies: pale yellow with few black markings to reddish brown, or almost completely black with few pale yellow markings (Kelton 1975, 1980). The antennae and legs are relatively long. Overwintered adults are much darker than the summer adults (Capinera 2001).

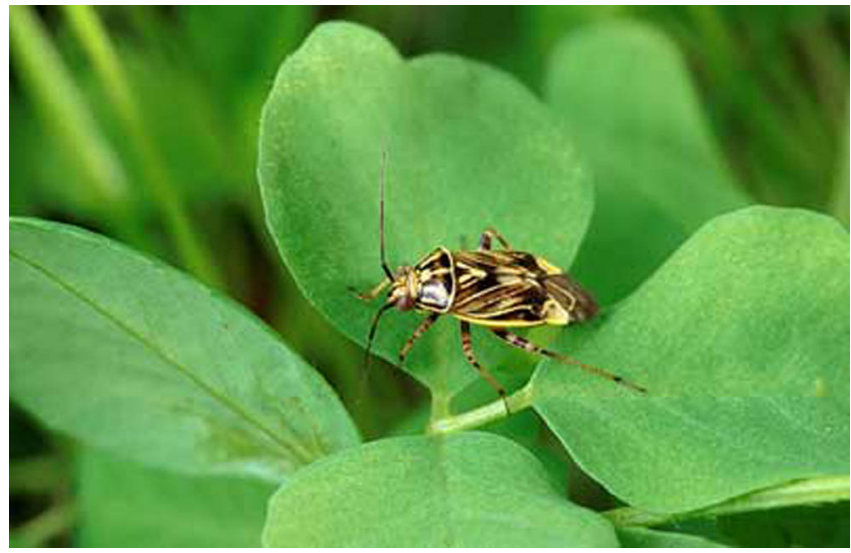

Figure 1. Adult tarnished plant bug, Lygus lineolaris (Palisot de Beauvois). Credits: Scott Bauer, USDA

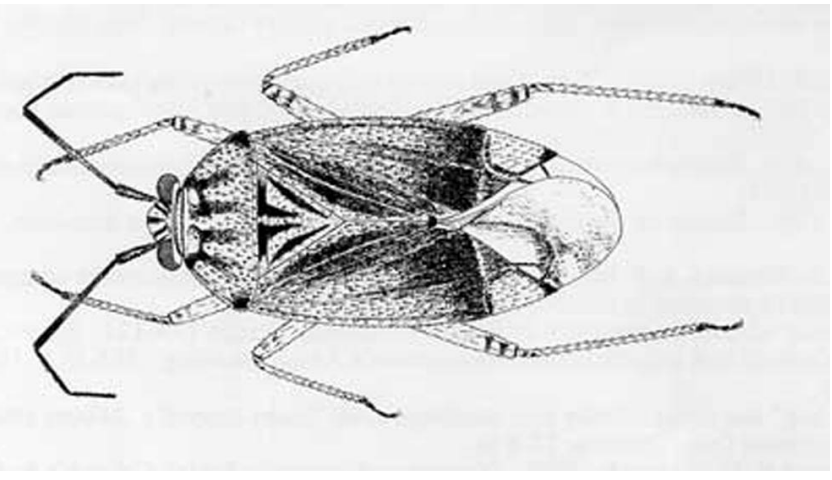

Figure 2. Adult tarnished plant bug, Lygus lineolaris (Palisot de Beauvois). Adapted from Kelton 1975. Credits: Division of Plant Industry

\section{Egg}

The egg is small, truncate and slightly curved. It is about $1 \mathrm{~mm}$ long and $0.25 \mathrm{~mm}$ wide. The top of the egg where it meets the surface of the plant tissue is flattened and has an opening through which the hatchling nymph emerges (Capinera 2001).

\section{Nymph}

Newly hatched nymphs are yellowish green and about $1 \mathrm{~mm}$ long. Older nymphs are yellow green to green and wingless. As they mature the nymphs develop yellow, green or black spots. Fourth and fifth stage nymphs have four black spots on the thorax and one on the abdomen. The head is light green. There are five nymphal instars. The full-grown nymph has wingpads and is about 4 to $4.5 \mathrm{~mm}$ long.

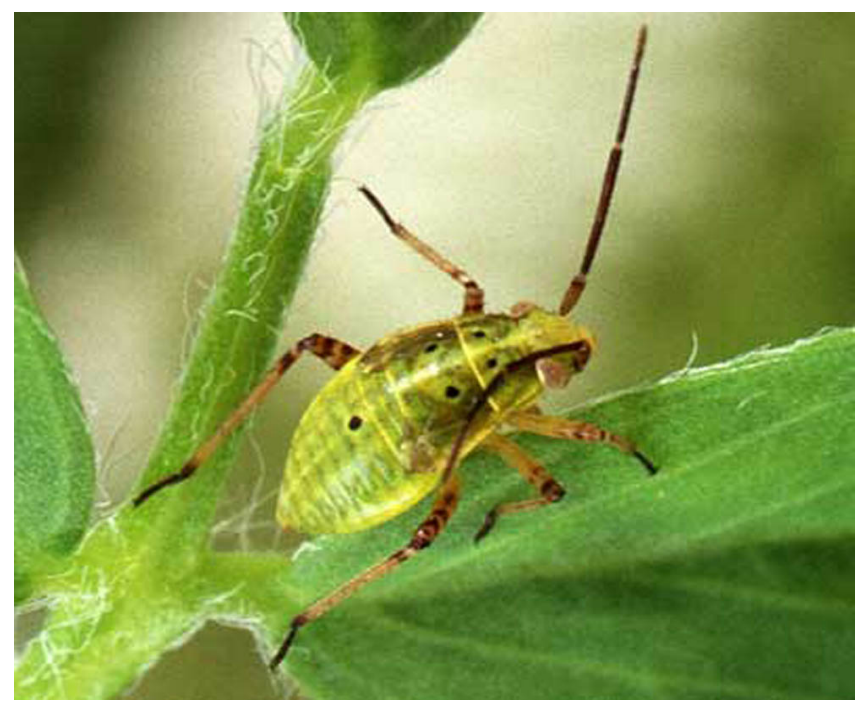

Figure 3. Fourth or fifth stage nymph of the tarnished plant bug, Lygus lineolaris (Palisot de Beauvois). Credits: Scott Bauer, USDA

\section{Life History}

Overwintering as adults, L. lineolaris can be found in dead weeds, leaf litter, under tree bark, and in rock piles in fields, timber margins, stream and ditch banks, and road rights-of-way. Adults become active in early spring and feed on newly developing buds and shoots. Most nursery damage occurs from mid-April to late June (Cleveland 1982, Haseman 1918, Anonymous 1988).

Oviposition is apparently restricted to composite host plants (non-conifers). Eggs are often deposited in leaf petioles or at the base of the leaf blade, but the preferred location varies with the crop attacked (Capinera 2001). In conifers, eggs are inserted into flowerlets or blossoms. Eggs are usually deposited singly, but occasionally more than one egg will be found in an oviposition site (Capinera 2001). After seven to 10 days, ca. $1 \mathrm{~mm}$ long, yellowish-green nymphs emerge and begin feeding. There are five nymphal stages. The life cycle is completed in three to four weeks. There are two to three generations per year (Haseman 1918, Sutherland et al. 1989, Knight 1941, Ridgeway and Gyrisco 1960). Population peaks for adults generally occur in early July, early August, and early September (Rakickas and Watson 1974, Ridgeway and Gyrisco 1960). 


\section{Hosts}

At least 385 host plants have been recorded for $L$. lineolaris. A majority of the hosts are in the subclasses Rosidae and Asteridae. Principal economic hosts are cotton, seed alfalfa, snap and lima beans, soybeans, apples, cherries, carrots, peaches, pears, strawberries, tomatoes, and nursery stock (Haseman 1918, Tingey and Pillemer 1977, Young 1986). Other vegetable crops subject to infestation are artichoke, asparagus, broccoli, cabbage, celery, chard, coriander, corn, cowpea, cucumber, eggplant, endive, escarole, faba bean, fennel, horseradish, lettuce, mustard, onion, parsnip, parsley, pea, pepper, potato, radish, spinach, squash, sweet potato, turnip and watermelon (Capinera 2001). Greenhouse hosts include asters, chrysanthemums, dahlias, impatiens, and marigolds.

As a conifer pest it attacks loblolly pine (Pinus taeda L.) (South 1986) and Choctawhatchee sand pine [Pinus clausa (Chapm.) Vasey var. immuginata Ward] seedlings in southern forest nurseries, and these are severely damaged by L. lineolaris feeding. Elsewhere, L. lineolaris damages white spruce [Picea glauca (Moench) Voss], lodgepole pine (Pinus contorta Dougl.), Douglas-fir [Pseudotsuga taxifolia (Poir.) Britt.] (Shrimpton 1984), and larch (Larix occidentalis Nutt.) (Sutherland et al. 1989).

\section{Damage}

The tarnished plant bug is among the most damaging of the true bugs and is known to transmit plant diseases. The bugs use their needle-like mouthparts to extract plant juices. Their feeding causes terminal growth to be yellowed or distorted thereby reducing plant growth and causing them to appear unthrifty. Leaves from damaged buds are sometimes ragged and discolored. Flowers from damaged buds sometimes fail to develop on one side or the whole bud aborts

\section{Survey and Detection}

Damage symptoms on most host plants attributed to Lygus bugs include leaf ragging, brown, discolored tissue, premature drop of buds, flowers, and fruit; cat-facing; increased number of vegetative branches; multiple crowns; elongation of internodes; split stem lesions; swollen nodes; and leaf crinkling (Tingey and Pillemer 1977). The appearance of plant parts damaged by L. lineolaris feeding has led to several color terms, e.g., "crazy cotton", "stop-back", "bushhead", "bushy-top." Adults and nymphs of $L$.

lineolaris feed by sucking plant juices and a watery saliva is simultaneously injected into the feeding site to aid in the breakdown of plant tissues. Symptoms appear within a few weeks after feeding injury. Generally, apical dominance is lost and weak multiple leaders appear. In conifer seedlings, terminal needles are thicker and shorter and the tip is often curled (Sutherland et al. 1989).

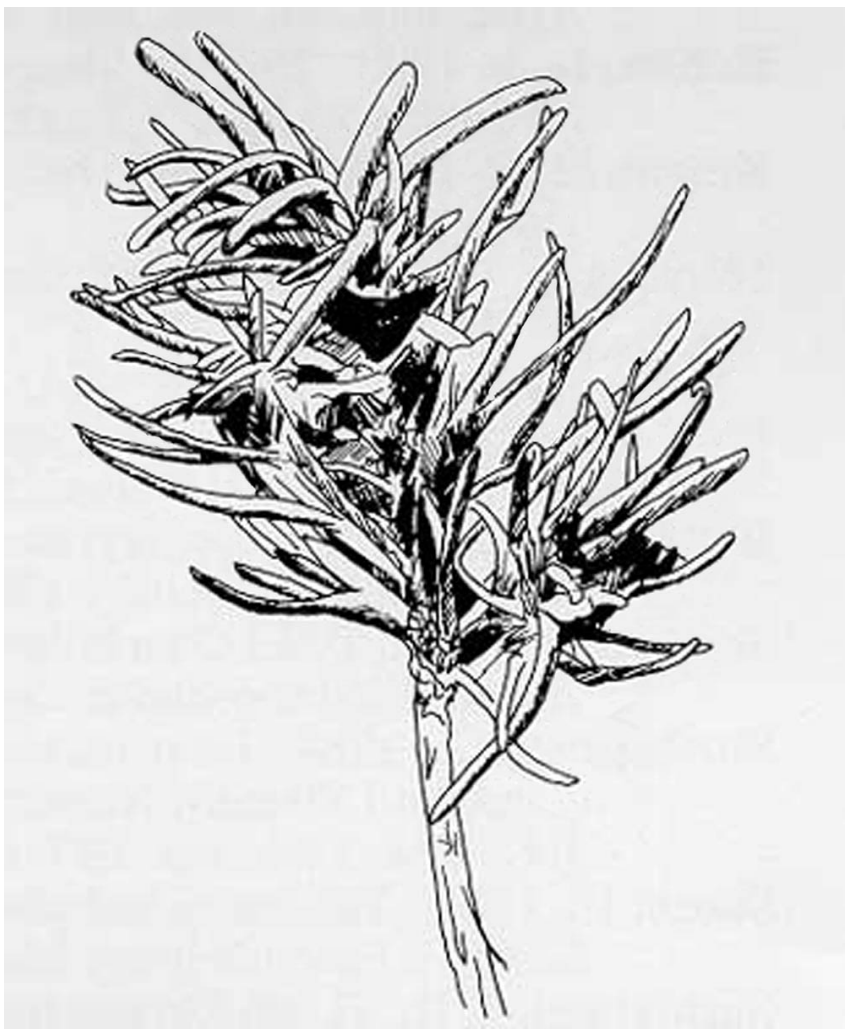

Figure 4. Typical appearance of conifer seedling damage by feeding of the tarnished plant bug, Lygus lineolaris (Palisot de Beauvois). Credits: Division of Plant Industry

Plant bug populations in crops tend to be aggregated or clumped. This necessitates large plant samples, if population assessments are to be accurate. White sticky traps at about $0.5 \mathrm{~m}$ are useful for detecting tarnished plant bugs in apple orchards and reportedly work well in vegetable crops (Capinera 2001). 


\section{Management}

The removal of preferred host plants from edges of nurseries and destruction of favorable overwintering sites will help to reduce the damages caused by L. lineolaris. Weed hosts include butterweed, fleabane, goldenrod, vetch, dock, and dog fennel.

Several insecticides are available to control populations of L. lineolaris. In Oregon, fenvalerate effectively controlled Lygus hesperus Knight in bare-rot, Douglas-fir seedling beds (Overhulser et al. 1986). For all other crops see the Insect Management Guide (

http://edis.ifas.ufl.edu/ TOPIC_GUIDE_Insect_Management_Guide).

Several parasitoids are known, but the egg parasite Anaphis iole Girault, and the nymphal parasites Leiophron uniformis (Gahan), Peristenus pallipes (Curtis) and P. pseudopallipes (Loan) (all Hymenoptera) are thought to be relatively important. The native parasites seem to be more effective at parasitizing Lygus on weeds than on crops. The imported parasitoid Peristenus digoneutis Loan (Hymenoptera: Braconidae) is reported to have decreased tarnished plant bug abundance by $75 \%$ in New Jersey. In addition, it seems not to have affected native parasitoids (Capinera 2001).

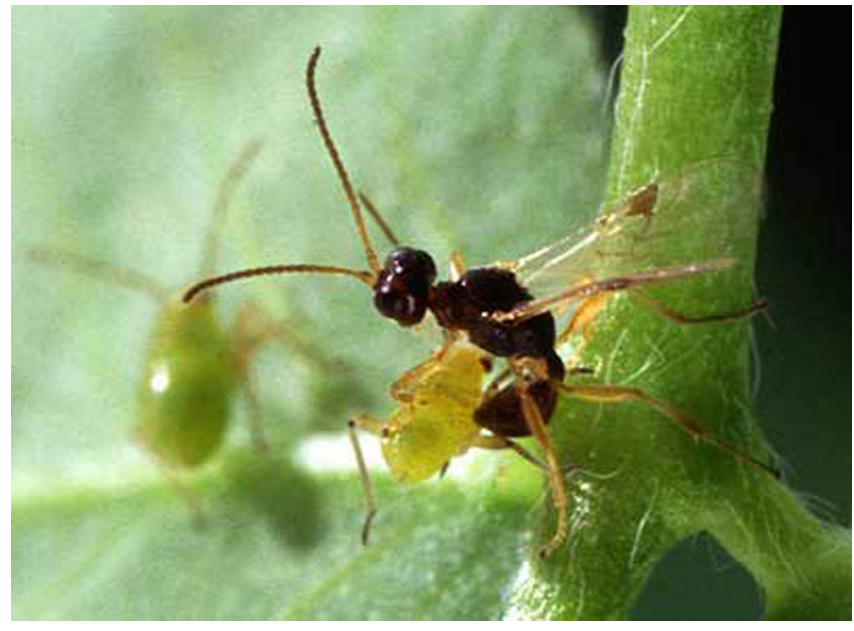

Figure 5. A quarter-inch-long parasitic wasp, Peristenus digoneutis Loan, prepares to lay an egg in a nymph of the tarnished plant bug, Lygus lineolaris (Palisot de Beauvois). Credits: Scott Bauer, USDA

\section{Selected References}

Anonymous. (Unknown). Key to bugs. Insect and Related Pests of Flowers and Foliage Plants. http://www.mrec.ifas.ufl.edu/Foliage/entomol/ncstate/ bugskey.htm (30 October 2001).

Anonymous. 1988. Lygus bug trapping results. Auburn University, Southern Forest Nursery Management Cooperative Newsletter. Spring 1988. 8 p.

Anonymous. (28 May 2001). Lygus lineolaris (Palisot). Agriculture \& Agri-Food Canada.

Capinera JL. 2001. Handbook of Vegetable Pests. Academic Press, San Diego. 729 p.

Cleveland TC. 1982. Hibernation and host plant sequence studies of tarnished plant bugs, Lygus lineolaris, in the Mississippi delta. Environmental Entomology 11: 1049-1052.

Day W, and Mahr S. (October 1998). Peristenus digoneutis, parasite of tarnished plant bug. Midwest Biological Control News Online. http://www.entomology.wisc.edu/mbcn/kyf510.html (30 October 2001).

Haseman L. 1918. The tarnished plant-bug and its injury to nursery stock. University of Missouri, College of Agriculture, Agricultural Experiment Station Research Bulletin 29. 26 p.

Kelton LA. 1980. The Plant Bugs of the Prairie Provinces of Canada. Heteroptera: Miridae. The Insects and Arachnids of Canada. Part 8. Canadian Government Publishing Centre. Hull, Quebec. 408 p.

Knight HH. 1941. The plant bugs, or Miridae, of Illinois. Bull. Illinois Natural History Survey. Vol. 22, Art. 1. 234 p.

Overhulser DL, Morgan PD, and Miller R. 1986. Control and impact of Lygus damage on 1-0 Douglas-fir seedlings. Pages 153-157. In: Proc. Combined Western Forest Nursery Council and Intermountain Nursery Assoc. Meeting. U.S. Department of Agriculture Forest Service General Technical Report RM-137. 
Rikackas RJ, Watson TF. 1974. Population trends of Lygus spp. And selected predators in strip-cut alfalfa. Environmental Entomology 3: 781-784.

Ridgeway RL, Gyrisco GG. 1960. Studies on the biology of the tarnished plant bug, Lygus lineolaris. Journal of Economic Entomology 53: 1063-1065.

Schowalter TD, Overhulser DL, Kanaski A, Stein JD, and Sexton J. 1986. Lygus hesperus as an agent of apical bud abortion in Douglas-fir nurseries in western Oregon. New Forests 1: 5- 15.

Shrimpton G. 1984. Four insect pests of conifer nurseries in British Columbia. Pages 119-121. In: Proc. Combined Western Nursery Council and Intermountain Nurserymen's Association Meeting. U.S. Department of Agriculture Forest Service General Technical Report INT-185.

South D. 1986. The "tarnished plant bug" can cause loblolly pine seedlings to be "bushy- topped." Auburn Univ. Southern Forest Nursery Management Cooperative, Number 27. 6 p.

Sutherland JR, Shrimpton GM, Sturrock RN. 1989. Diseases and insects in British Columbia forest seedling nurseries. Canada-British Columbia For. Resource Development Agreement Report. 065. 85 p.

Tingey WM, Pillemer EA. 1977. Lygus bugs: crop resistance and physiological nature of feeding injury. Bulletin of the Entomological Society of America 23: 277-287.

Young OP. 1986. Host plants of the tarnished plant bug, Lygus lineolaris (Heteroptera: Miridae). Annals of the Entomological Society of America 79: 747-762. 